\title{
The Identity of Jesus: Nordic Voices
}

\section{Ed. by Samuel Byrskog, Tom Holmén and Matti Kankaanniemi}

[Die Identität Jesu. Nordische Stimmen.]

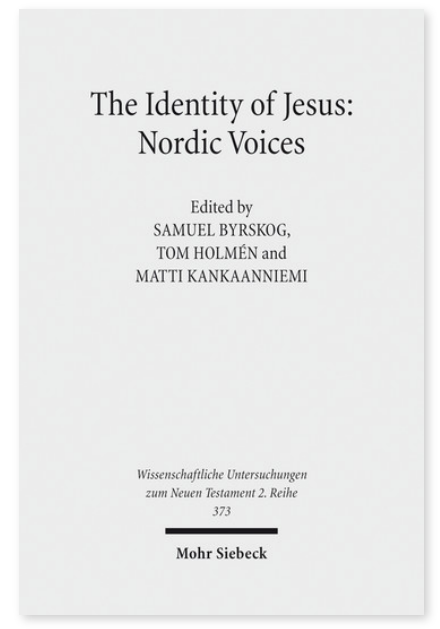

2014. X, 250 Seiten. WUNT II 373

ISBN 978-3-16-152402-8

DOI 10.1628/978-3-16-152402-8

eBook PDF 89,00€

ISBN 978-3-16-152204-8

fadengeheftete Broschur 89,00€
Veröffentlicht auf Englisch.

Ein Großteil der Jesusforschung konzentriert sich auf das so genannte Selbstverständnis Jesu. Aufgrund der aktuellen Gewichtung auf die subjektive Wahrnehmung und den Erinnerungsprozess in der Methodik der Jesusforschung ist es jedoch sinnvoll, die Fragestellungen neu zu konzipieren. Die Autoren dieses Bandes behandeln die Frage nach der Identität Jesu aus verschiedenen Blickwinkeln. Die Perspektiven reichen von der der vergleichenden Religionswissenschaften bis zu Analysen der Erzählungen Jesu, einiger seiner Schlüsselerlebnisse und real existierender Persönlichkeiten des Judentums im ersten Jahrhundert. Das Ziel dieser Aufsatzsammlung ist es, informative und aktuelle Perspektiven einer der zentralsten Fragestellungen des Fachgebiets abzubilden. Um wichtige Aspekte der Forschung zum historischen Jesus abzudecken, wurden die Vorträge des ersten nordischen Symposiums zum historischen Jesus in Åbo im Jahre 2010 abgeändert und zusammengestellt. Mit Beiträgen von:Jostein Ådna, Renate Banschbach-Eggen, Per Bilde, Samuel Byrskog, Tobias Hägerland, Tom Holmén, Matti Kankaanniemi, Thomas Kazen, Hans Kvalbein, Kari Syreeni

\section{Inhaltsübersicht}

Table of Contents: Kari Syreeni: The Identity of the Jesus Scholar: Diverging Preunderstandings in Recent Jesus Research - Per Bilde: Approaching the Issue of the Originality of Jesus - Matti Kankaanniemi: Jesus the Son of Joseph: Reflections of FatherSon Relationship in the Ministry of Jesus - Tobias Hägerland: A Prophet like Elijah or according to Isaiah? Rethinking the Identity of Jesus - Hans Kvalbein: Jesus as Preacher of Kingdom - Samuel Byrskog: The Didactic Identity and Authority of Jesus - Reconsidered - Renate Banschbach-Eggen: Understanding the Identity of Jesus on the Basis of his Parables - Thomas Kazen: Revelation, Interpretation, Tradition: Jesus, Authority and Halakic Development - Jostein Ådna: The Role of Jerusalem in the Mission of Jesus - Tom Holmén: Caught in the Act: Jesus Starts the New Temple - A Continuum Study of Jesus as Temple Founder

Samuel Byrskog Born 1957; 1994 ThD at Lund University; currently Professor of New Testament Studies and Dean of the Faculty of Theology at Lund University.

Tom Holmén Born 1963, 1999 ThD from Åbo Akademi University; currently adjunct professor of New Testament Exegetics at Åbo Akademi University and University of Helsinki.

Matti Kankaanniemi Born 1974; 2002 M.Sc.Econ from Turku School of Economics and Busines Administration; 2010 ThD from Åbo Akademi University; currently lecturer of Biblical Studies and Social Sciences at Iso Kirja College, Keuruu Finland.

Jetzt bestellen:

https://mohrsiebeck.com/buch/the-identity-of-jesus-nordic-voices-9783161524028?no_cache=1 order@mohrsiebeck.com Telefon: $+49(0) 7071-923-17$ Telefax: $+49(0) 7071-51104$ 